\title{
Produktivitas Ulat Hongkong (Tenebrio molitor) pada Media Pakan yang Berbeda
}

\author{
Productivities of Tenebrio larva (Tenebrio molitor) in Different Feeding Media \\ D. G. P. L. Hapsari ${ }^{1}$, A. M. Fuah ${ }^{1}$, \& Y. C. Endrawati ${ }^{1}$ \\ ${ }^{1}$ Departemen Ilmu Produksi dan Teknologi Peternakan, Fakultas Peternakan, \\ Institut Pertanian Bogor, Jln. Agatis Kampus IPB Dramaga, Bogor 16680 \\ Email koresponden author: y.cahya82@gmail.com
}

\begin{abstract}
Mealworm is the larva stage of Tenebrio molitor $L$. beetle which is used for pet feed. The aim of this research was to analyze the effect of feeding medias to support the growth of mealworm. The compared feeding media were $100 \%$ dry tofu by product as a control, $100 \%$ rice bran, $100 \%$ rice husk, $50 \%$ dry tofu by product $+\mathbf{5 0} \%$ rice bran, $\mathbf{5 0} \%$ dry tofu by product $+\mathbf{5 0} \%$ rice husk and $\mathbf{5 0} \%$ rice husk $+50 \%$ rice bran. Randomized Complete Design was used as the experimental design with 6 treatments with 3 replications for each treatment. The result showed that body weight and body length were not significantly different $(\mathrm{P}>0.05)$ among media, but mortality and pupation were significantly different $(\mathbf{P}<\mathbf{0 . 0 5})$. The feeding media with $\mathbf{5 0 \%}$ dry tofu by product $+\mathbf{5 0 \%}$ rice bran are better to use because it can increase feed consumption, percentage of pupation, and reduce mortality.
\end{abstract}

Keywords: dry tofu by product, growth, mealworm, rice bran, rice husk

\section{PENDAHULUAN}

Peternakan ulat hongkong merupakan salah satu usaha potensial untuk dikembangkan menjadi usaha peternakan rakyat. Selain karena cara budidaya yang mudah, peternakan ulat hongkong juga mempunyai peluang bisnis yang cukup menjanjikan mengingat pangsa pasar yang sangat kondusif di Indonesia. Di Indonesia, ulat hongkong dimanfaatkan sebagai pakan hewan peliharaan seperti burung, ikan, landak mini, semut rangrang, dan ular. Penggunaan ulat hongkong yang semakin meluas menyebabkan permintaan ulat hongkong mengalami peningkatan. Berdasarkan hasil survei yang dilakukan, kebutuhan ulat hongkong untuk wilayah Jakarta, Bogor, Depok, Tangerang, dan Bekasi (Jabodetabek) sekitar 73 ton/bulan yang dirinci dari kebutuhan di Bogor 12 ton/ bulan, Jakarta 20 ton/bulan, Bekasi 15 ton/bulan, Depok dan Tangerang yang masing-masing mencapai 13 ton/ bulan (Yusdira et al. 2016), sehingga dibutuhkan metode pemeliharaan yang tepat. Salah satunya adalah dengan penggunaan media pemeliharaan yang tepat untuk meningkatan produksinya.

Media pemeliharaan ulat hongkong digunakan sebagai pakan, tempat bereproduksi dan berproduksi sehingga mampu mempengaruhi pertumbuhan ulat. Peternak ulat hongkong umumnya memanfaatkan ampas tahu kering sebagai media pakan selama pemeliharaan. Ampas tahu merupakan limbah dalam bentuk padatan pasta dari bubur kedelai yang diperas untuk diambil sarinya pada proses pembuatan tahu (Wiriano 1985). Sekam padi merupakan bagian pelindung terluar dari padi (Oryza sativa) yang akan terpisah dari butiran beras dan menjadi bahan sisa atau limbah penggilingan (Hsu dan Luh 1980). Proses penggilingan padi menurut Haryadi (2006) menghasilkan sekam sekitar 20\%-30\%, dedak padi $8 \%-12 \%$, dan beras giling 50\%-63,5\% dari bobot awal gabah. Sekam dengan persentase yang tinggi dapat menimbulkan masalah lingkungan jika tidak dimanfaatkan dengan baik. Dedak padi merupakan hasil penggilingan padi dengan nutrisi yang baik, yaitu protein kasar 8,5\%, serat kasar 17,0\%, lemak kasar 4,2\%, dan BETN 43,7\% (Hartadi et al. 1980).

Berdasarkan hal tersebut dan kajian penelitian sebelumnya, perlu adanya penelitian terkait pemanfaatan hasil penggilingan untuk media pertumbuhan ulat hongkong. Pemilihan hasil penggilingan padi sebagai media pakan karena bahan tersebut tersedia diberbagai tempat dan memiliki harga yang murah. Menurut Suharno (1979) sekam berpotensi sebagai pakan dengan kadar air 9,02\%, protein kasar 3,03\%, dan serat kasar 35,68\%. Tujuan penelitian untuk menganalisis perbedaan pengaruh media pakan yang berbeda terhadap pertumbuhan ulat hongkong (Tenebrio molitor) yang terdiri dari bobot badan, pertambahan bobot badan, pertambahan panjang badan.

\section{MATERI DAN METODE}

Waktu dan Tempat Penelitian

Penelitian ini dilakukan selama tiga bulan mulai dari bulan Januari hingga bulan April 2017. Penelitian ini dilaksanakan di Laboratorium Lapangan Non Ruminansia dan Satwa Harapan, Departemen Ilmu Produksi dan Teknologi Peternakan, Fakultas Peternakan, Institut Pertanian Bogor. 
Materi dan Pelaksanaan Penelitian

Materi yang digunakan dalam penelitian ini adalah ulat hongkong sebanyak 1800 ekor dengan umur 21 hari yang diperoleh dari Sugeng Jaya Farm dengan bobot rata-rata 0,07 g. Media pakan terdiri dari ampas tahu kering, dedak padi, dan sekam padi. Pelumas kendaraan bekas sebagai bahan pengisi alas kaki rak kayu, dan kentang sebagai sumber air minum. Komposisi kimia media pakan yang digunakan dapat dilihat pada Tabel 1. Baskom beralaskan media pakan sebanyak 18 unit berukuran $60 \times 30 \times 30$ $\mathrm{cm}$ dengan ketinggian alas 2,54 $\mathrm{cm}$ dengan perbandingan masing masing 50:50.

\section{HASIL DAN PEMBAHASAN}

Kondisi Lokasi Penelitian

Suhu merupakan faktor penting yang mempengaruhi aktifitas serangga(Flukerfarm 2005). Secara umum, serangga bersifat poikilothermi, yaitu suhu tubuhnya naik dan turun mengikuti suhu lingkungan (Triplehorn dan Johnson 2005). Pemeliharaan ulat hongkong menggunakan baskom plastik. Rataan suhu dan kelembaban lokasi penelitian disajikan pada Tabel 2. Rataan suhu dan kelembaban dalam penelitian ini termasuk dalam kisaran yang mendukung kehidupan ulat hongkong.

Tabel 1. Hasil analisis proksimat ampas tahu kering, dedak padi, dan sekam padi

\begin{tabular}{lcccccc}
\hline Komponen & $\begin{array}{c}\text { Ampas tahu kering } \\
\text { (A) }\end{array}$ & $\begin{array}{c}\text { Dedak padi } \\
\text { (D) }\end{array}$ & $\begin{array}{c}\text { Sekam padi } \\
(\mathrm{S})\end{array}$ & $\begin{array}{c}\text { Ampas } \\
\text { tahu:Dedak padi } \\
\text { (AD) }\end{array}$ & $\begin{array}{c}\text { Ampas } \\
\text { tahu:Sekam padi } \\
\text { (AS) }\end{array}$ & $\begin{array}{c}\text { Dedak } \\
\text { padi:Sekam padi } \\
\text { (DS) }\end{array}$ \\
\hline Bahan kering & 86,75 & 86,80 & 90,84 & 89,28 & 89,21 & 89,59 \\
Protein kasar & 21,92 & 11,36 & 8,33 & 17,18 & 15,49 & 10,82 \\
Serat Kasar & 28,70 & 29,14 & 41,96 & 31,15 & 31,46 & 37,69 \\
Kadar Air & 13,25 & 13,20 & 9,16 & 10,72 & 10,79 & 10,41 \\
\hline
\end{tabular}

\section{Rancangan Penelitian}

Rancangan yang digunakan adalah rancangan acak lengkap (RAL). Terdapat 6 taraf perlakuan jenis media yaitu A (100\% ampas tahu) sebagai kontrol, D (100\% dedak padi), S (100\% sekam padi), AD (50\% ampas tahu $+50 \%$ dedak padi), AS (50\% ampas tahu $+50 \%$ sekam padi), dan DS (50\% dedak padi $+50 \%$ sekam padi). Setiap taraf perlakuan diulang sebanyak 3 kali sehingga terdapat 18 unit percobaan. Model matematika yang digunakan menurut Mattjik dan Sumertajaya (2013) adalah:

$$
Y i j=\mu+P i+\varepsilon i j
$$

Yij = Nilai konsumsi pakan, pertambahan bobot badan, panjang badan, suhu dan kelembaban pada media pemeliharaan ke-i (ampas tahu, dedak padi; sekam padi, dedak padi; ampas tahu, sekam padi) dan ulangan ke-j (1, 2, 3, dan 4);

$\mu=$ Nilai tengah umum konsumsi pakan, pertambahan bobot badan, panjang badan, suhu dan kelembaban dalam kandang;

$\mathrm{Pi}=$ Pengaruh media pemeliharaan ke-i (A, D, S, AD, AS, dan DS); dan

$\varepsilon \mathrm{ij}=$ Pengaruh galat percobaan pada media sarang ke-i (A, D, S, AD, AS, dan DS) pada ulangan ke-j (1, 2, 3 , dan 4).

Data yang diperoleh dianalisis ragam atau ANOVA dan bila diketahui beda nyata dilanjutkan dengan uji jarak berganda Duncan 5\% untuk mengetahui perbedaan antar perlakuan. Peubah yang diamati meliputi: konsumsi pakan, pertambahan bobot badan, panjang badan, bobot badan, suhu dan kelembaban.
Menurut Borror et al. (1982), suhu optimum serangga sekitar $26{ }^{\circ} \mathrm{C} \cdot \mathrm{T}$. molitor mampu mengekstraksi uap air dari udara apabila kelembaban melebihi 90\%, dengan demikian, kisaran kelembaban yang dapat ditolerir ulat hongkong adalah 20\%-90\%. Culin (2008) menjelaskan bahwa dengan semakin rendah suhu lingkungan, maka pertumbuhan ulat hongkong akan lambat, bahkan dapat mencapai 6 bulan. Perbedaan suhu dapat mempengaruhi lamanya waktu yang dibutuhkan untuk 1 siklus pertumbuhan.

\section{Konsumsi Pakan}

Pakan merupakan kebutuhan pokok makhluk hidup dalam memenuhi kebutuhan zat nutrisi seperti vitamin, energi, protein, mineral, dan zat lainnya yang digunakan untuk proses pertumbuhan, reproduksi dan produksi dapat mempengaruhi sifat-sifat morfologi seperti ukuran dan warna tubuh (Borror et al. 1982). Serangga memiliki toleransi yang tinggi terhadap serat kasar sehingga akan sangat menguntungkan karena banyak bahan pakan berserat kasar tinggi yang memiliki harga murah dan dapat menjadi pilihan dalam menyusun ransum (Saefulhadjar 2005). Konsumsi Bahan kering pakan ulat hongkong pada hari ke 28-60 disajikan pada Tabel 3.

Ulat yang digunakan berumur 28 hari karena pada umur tersebut ulat mampu beradaptasi terhadap perlakuan pakan yang diberikan. Konsumsi pakan pada umur 28-60

Tabel 2. Suhu dan kelembaban laboratorium

\begin{tabular}{lcc}
\hline Waktu & Suhu $\left({ }^{\circ} \mathrm{C}\right)$ & Kelembaban $(\%)$ \\
\hline Pagi & $25,58 \pm 1,33$ & $86,36 \pm 5,79$ \\
Sore & $26,20 \pm 2,26$ & $80,45 \pm 10,76$ \\
\hline
\end{tabular}

Keterangan: Selama pemeliharaan pada bulan April 2017. 
hari ternyata tidak berpengaruh nyata $(\mathrm{P}>0,05)$ terhadap perbedaan media pemeliharaan. Pada umur 28-38 hari konsumsi pakan ulat dengan media pemeliharaan AD cenderung lebih tinggi dibanding dengan penggunaan media pemeliharaan ampas tahu sebagai kontrol. Konsumsi pakan umur 39-49 hari mengalami penurunan pada media pemeliharaan A dan AD. Hal tersebut dikarenakan ulat hongkong mengalami molting atau pergantian kulit. Pergantian kulit pada serangga ditandai dengan serangkaian kejadian fisiologis yang dikaitkan dengan apolysis dan ecdysis. Apolisis secara khusus berkaitan dengan pelepasan secara bertahap epidermis anteroseptor dari kutikula, sedangkan ekdisis berkaitan dengan pengguguran kutikula lama (Hepburn 1985). Ulat hongkong yang sedang mengalami molting umumnya tidak membutuhkan pakan. Sari dan Hartiningsih (2014) menyatakan konsumsi pakan ulat hongkong mencapai 0,053-0,621 g/ekor/hari.

Konsumsi pakan ulat hongkong umur 50-60 hari pada media pemeliharaan AD mengalami peningkatan drastis sebesar $0,120 \mathrm{~g} / \mathrm{ekor} / \mathrm{hari}$. Hal ini terjadi karena ulat hongkong umur 50-60 hari merupakan umur menjelang tahap pupasi sehingga ulat hongkong meningkatkan konsumsi pakannya untuk persediaan energi ketika memupa. Paryadi (2003) menyatakan bahwa ulat hongkong mulai menjadi pupa pada umur 77 hari. Sihombing (1999) menyatakan bahwa 69,1\% dari konsumsi pakan dipengaruhi oleh umur sedangkan 30,9\% dipengaruhi oleh faktor lain seperti suhu dan kelembaban.

\section{Bobot Badan dan Pertambahan Bobot Badan}

\section{Bobot Badan}

Bobot badan pada awal penelitian (sebelum diberikan perlakuan) sekitar 0,07 g/ekor. Bobot badan ulat hongkong mengalami peningkatan sesuai dengan pertambahan umur. Bobot badan ulat hongkong pada umur 28-60 hari disajikan pada Tabel 4. Ulat yang mendapat pakan AD memiliki bobot yang lebih tinggi karena konsumsi pakan juga tinggi seperti yang ditunjukkan pada Tabel 4.

Ulat hongkong pada umur 50-60 hari pada media pemeliharaan ampas tahu kering dan kombinasi media pemeliharaan ampas tahu kering dan dedak memiliki rataan bobot badan yang tinggi yaitu 0,134 dan 0,133 g/ekor. Analisis ragam bobot badan ulat hongkong menunjukkan bahwa pemberian media pemeliharaan yang berbeda tidak berpengaruh nyata $(\mathrm{P}>0,05)$ terhadap bobot badan ulat hongkong. Bobot badan ulat hongkong umur 50-60 hari dengan media pemeliharaan kontrol lebih tinggi dibandingkan dengan media lain yakni $0,134 \mathrm{~g} /$ ekor. Paryadi (2003) menyatakan bahwa bobot badan ulat hongkong pada umur 84 hari berkisar 0,128-0,140 g/ekor.

\section{Pertambahan Bobot Badan}

Rataan pertambahan bobot badan berkisar 0,0080,043 mg/ekor. Perbedaan media pemeliharaan tidak berpengaruh nyata $(\mathrm{P}>0,05)$ terhadap pertambahan bobot badan ulat hongkong. Pertambahan bobot badan pada umur 28 hingga 60 hari disajikan pada Gambar 1.

Tabel 3. Konsumsi bahan kering pakan ulat hongkong pada hari ke 28-60

\begin{tabular}{|c|c|c|c|c|}
\hline \multirow[t]{3}{*}{ Perlakuan } & \multicolumn{3}{|c|}{ Umur (hari ke-) } & \multirow[t]{3}{*}{ Rataan } \\
\hline & $28-38$ & $39-49$ & $50-60$ & \\
\hline & \multicolumn{3}{|c|}{ g/ekor/hari } & \\
\hline Ampas tahu (A) & $0,032 \pm 0,001$ & $0,030 \pm 0,004$ & $0,062 \pm 0,022$ & $0,041 \pm 0,009$ \\
\hline Dedak padi (D) & $0,024 \pm 0,003$ & $0,029 \pm 0,008$ & $0,030 \pm 0,013$ & $0,028 \pm 0,008$ \\
\hline Sekam padi (S) & $0,025 \pm 0,006$ & $0,043 \pm 0,012$ & $0,061 \pm 0,024$ & $0,043 \pm 0,014$ \\
\hline Ampas tahu:Dedak padi (AD) & $0,033 \pm 0,004$ & $0,028 \pm 0,001$ & $0,120 \pm 0,050$ & $0,060 \pm 0,018$ \\
\hline Ampas tahu:Sekam padi (AS) & $0,025 \pm 0,005$ & $0,027 \pm 0,006$ & $0,047 \pm 0,042$ & $0,033 \pm 0,018$ \\
\hline Dedak padi:Sekam padi (DS) & $0,020 \pm 0,004$ & $0,030 \pm 0,002$ & $0,016 \pm 0,016$ & $0,037 \pm 0,007$ \\
\hline
\end{tabular}

Tabel 4. Bobot badan ulat hongkong umur 28-60 hari

\begin{tabular}{lccc}
\hline Perlakuan & \multicolumn{3}{c}{ Umur (hari ke-) } \\
\cline { 2 - 4 } & $28-38$ & $39-49$ & $50-60$ \\
\cline { 2 - 4 } & & g/ekor & $0,134 \pm 0,008$ \\
\hline Ampas tahu (A) & $0,073 \pm 0,012$ & $0,101 \pm 0,004$ & $0,128 \pm 0,004$ \\
Dedak padi (D) & $0,084 \pm 0,006$ & $0,115 \pm 0,003$ & $0,116 \pm 0,019$ \\
Sekam padi (S) & $0,084 \pm 0,008$ & $0,092 \pm 0,024$ & $0,133 \pm 0,011$ \\
Ampas tahu:Dedak padi (AD) & $0,081 \pm 0,003$ & $0,124 \pm 0,005$ & $0,125 \pm 0,020$ \\
Ampas tahu:Sekam padi (AS) & $0,080 \pm 0,005$ & $0,113 \pm 0,008$ & $0,115 \pm 0,009$ \\
Dedak padi:Sekam padi (DS) & $0,081 \pm 0,007$ & $0,104 \pm 0,007$ &
\end{tabular}




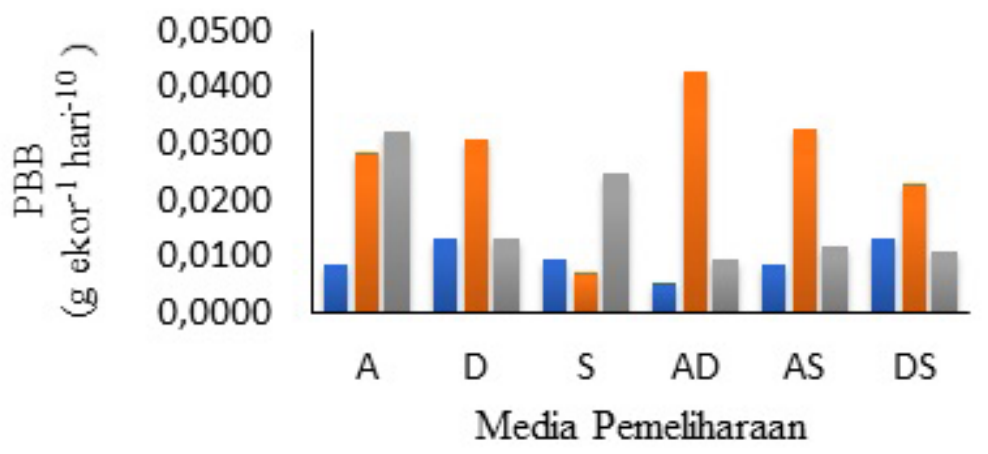

- Hari 28-38 = Hari 39-49 = Hari 50-60

Gambar 1. Pertambahan bobot badan ulat hongkong

Keterangan: $\mathrm{A}=$ Ampas tahu $100 \%$ (kontrol), $\mathrm{D}=$ Dedak padi $100 \%$, S= Sekam padi $100 \%$, $\mathrm{AD}=$ Ampas tahu $50 \%+$ Dedak padi $50 \%$, AS= Ampas tahu $50 \%+$ Sekam padi $50 \%$,

DS= Dedak padi $50 \%+$ Sekam padi $50 \%$

Ulat hongkong dengan media pemeliharaan $\mathrm{AD}$ menghasilkan pertambahan bobot badan tertinggi yaitu sebesar 0,0427 g/ekor/10 hari pada hari ke 39-49. Hal ini disebabkan karena media AD memiliki kandungan nutrisi yang cukup baik untuk pertumbuhan ulat hongkong. Widyatmoko (1996) menyatakan bahwa ampas tahu memiliki kandungan energi metabolis (EM) sebesar 2830 $\mathrm{kkal} / \mathrm{kg}$ dan dedak padi memiliki kandungan EM sebesar $2900 \mathrm{kkal} / \mathrm{kg}$. Saefulhadjar (2005) menjelaskan bahwa level protein $16 \%$ dengan EM lebih dari $2300 \mathrm{kkal} / \mathrm{kg}$ akan memberikan PBB yang baik pada ulat hongkong. Pada minggu 2-3 pertambahan bobot badan ulat dengan media pemeliharaan AD lebih rendah daripada media pemeliharaan A (0,0093 dan 0,0323 g/ekor/10 hari). Pertambahan bobot badan ulat hongkong pada umur 39-60 hari dengan media pemeliharaan AD mengalami penurunan drastis. Hal ini menunjukkan bahwa pada umur tersebut ulat hongkong mengalami molting atau pergantian kulit. Saefulhadjar (2005) menyatakan bahwa jumlah molting dipengaruhi oleh suhu, kualitas dan kuantitas pakan. Kualitas dan kuantitas pakan mempengaruhi proses metabolisme dalam tubuh sehingga apabila serangga mengalami defisiensi zat makanan tertentu dalam pakannya menyebabkan proses metabolism akan terganggu.

Molting merupakan mekanisme dasar pertumbuhan pada serangga yang dikondisikan dengan kutikula (Wiglesworth 1792). Terjadinya molting dikontrol oleh 3 hormon yaitu PTTH (hormon protoasikotropik), hormon juvenile, dan hormon ekdison. Apabila hormon juvenile tidak ada, maka larva akan berubah menjadi pupa (Borror et al. 1982). Pertumbuhan ulat hongkong terhalang oleh dinding tubuh yang sangat keras sehingga terjadi pergantian kulit atau molting pada ulat yang membuat ukuran badan semakin membesar. Bethney (2003) menyatakan bahwa ulat akan mengalami ganti kulit sebanyak 20 kali selama siklus hidupnya. Sihombing (1999) menyatakan bahwa setelah proses molting, bobot badan ulat meningkat seperti yang ditunjukkan pada Tabel 4.
Gambar 1 menunjukkan pertambahan bobot badan pada ulat hongkong dengan menggunakan media A dan $\mathrm{S}$ meningkat bersamaan dengan bertambahnya umur. Hal tersebut dikarenakan ampas tahu merupakan bahan pakan sumber protein yang mengandung protein kasar cukup tinggi berkisar 18\%-25\%, lemak 4.5\% dan serat kasar $18.21 \%$ dan mengandung sedikit karbohidrat sehingga pertumbuhan ternak lebih cepat (Widyatmoko 1996). Sekam padi memiliki nilai nutrisi yang rendah ditandai dengan kandungan serat kasar tinggi, protein dan energi rendah sehingga menyebabkan siklus hidup ulat lebih lama. Saefulhadjar (2005) kandungan protein 7\% nyata tidak memberikan angka PBB yang baik, dan dapat dikatakan tidak mencukupi bagi kebutuhan untuk tumbuh optimal ulat hongkong.

\section{Pertambahan Panjang Badan}

Pertambahan panjang badan merupakan salah satu parameter pertumbuhan pada ulat hongkong. Pertambahan panjang badan ulat hongkong dalam penelitian ini antara $-1,617$ hingga 2,976 mm/ekor/10 hari. Pertambahan panjang badan pada ulat hongkong umur 28 hingga 60 hari disajikan pada Gambar 2. Media pemeliharaan dengan menggunakan DS pada minggu 0-1 menghasilkan panjang badan yang cukup tinggi yaitu 2,976 mm/ekor sedangkan pada media pemeliharaan AS menghasilkan panjang badan yang cukup rendah yaitu $0,890 \mathrm{~mm} /$ ekor pada minggu $0-1$. Minggu 1 merupakan fase awal pada pertumbuhan ulat hongkong. Hairani (2006) menyatakan bahwa fase awal pertumbuhan ulat hongkong ditunjukkan dengan pertambahan panjang badan sedangkan pada fase akhir adalah pertambahan bobot badan. Media pemeliharaan yang menggunakan dedak $100 \%$ (D) menghasilkan pertambahan panjang badan tertinggi yaitu 2,316 mm/ ekor/10 hari sedangkan media pemeliharaan yang menggunakan sekam 100\% (S) menghasilkan pertambahan panjang badan cukup rendah yaitu $1,097 \mathrm{~mm} / \mathrm{ekor} / 10$ hari pada umur 50-60 hari.

Pada umur 50-60 hari merupakan waktu dimana ulat hongkong mulai memasuki masa pupasi yang ditandai 


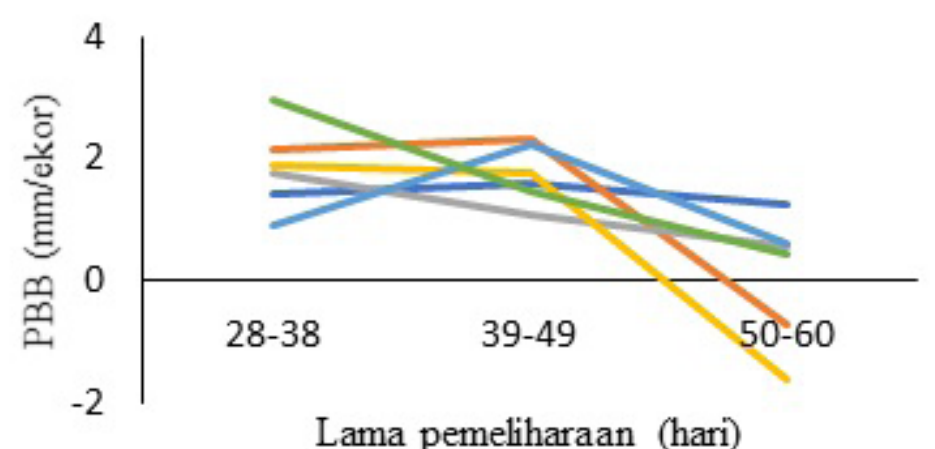

Lama pemeliharaan (hari)

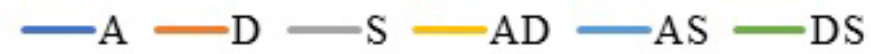

Gambar 2. Pertambahan panjang badan ulat hongkong umur 28-60 hari.

Keterangan: $\mathrm{A}=$ Ampas tahu $100 \%$ (kontrol), $\mathrm{D}=$ Dedak padi $100 \%, \mathrm{~S}=$ Sekam padi $100 \%$, $\mathrm{AD}=$ Ampas tahu $50 \%+$ Dedak padi $50 \%, \mathrm{AS}=$ Ampas tahu $50 \%+$ Sekam padi $50 \%$, DS $=$ Dedak padi $50 \%+$ Sekam padi $50 \%$

dengan mengalami sedikit pertambahan panjang badan atau bahkan mengalami pemendekan. Pertambahan panjang pada umur 40 hari dengan media pemeliharaan AD hanya mencapai $17,73 \mathrm{~mm} /$ ekor/10 hari sedangkan hasil penelitian Hutauruk (2005), ulat hongkong mempunyai pertambahan panjang badan tertinggi pada umur 40-50 hari yaitu 43-44 mm/ekor/10 hari. Pertumbuhan ulat hongkong dengan media pemeliharaan AD mengalami penurunan panjang badan yaitu sebesar $-16,17 \mathrm{~mm} / \mathrm{ekor} / 10$ hari. Hal ini disebabkan karena ulat hongkong mengalami proses persiapan memupa pada umur 50-60 hari. Menurut Hutauruk (2005) pertumbuhan panjang badan ulat hongkong akan menjadi lambat dan ukuran tubuh memendek.

Rosadi (2001) menyatakan bahwa stadium larva merupakan stadium makan sehingga perkembangan pada stadium tersebut dipengaruhi oleh faktor komposisi dan kandungan pakan. Pakan yang kurang sesuai akan menyebabkan siklus hidup menjadi lebih panjang. Sekam memiliki kandungan nutrisi yang cukup rendah apabila dibandingkan dengan media pemeliharaan lainnya sehingga siklus hidup ulat menjadi lebih panjang. Gambar 2 menunjukkan bahwa pada umur 28-60 hari rataan petambahan panjang badan ulat dengan media pemeliharaan A, D, S, AD, AS, dan DS sebesar 1,420; 1,$243 ; 1,148 ; 0,678 ; 1,254$; dan 1,622 mm/ekor.

\section{Pupasi}

Pupa merupakan tahapan siklus hidup ulat hongkong yang tidak makan dan minum, berwarna kuning dan mirip mumi kumbang dewasa (Hutauruk 2005). Fase pupasi biasanya juga disebut fase diam karena pada fase ini ulat berhenti makan dan jarang terlihat aktifitasnya, terkecuali jika terdapat gangguan dari lingkungan (Partosoedjono 1985). Menurut Singh (2003) Pupa T. molitor L. ini mampu mencapai panjang 15 $\mathrm{mm}$, lebar $5 \mathrm{~mm}$ dan berwarna putih ketika pertama kali terbentuk kemudian menjadi berwarna cokelat kekuningan. Persentase pupasi pada ulat hongkong umur 28 hingga 60 hari disajikan pada Tabel 5.
Proses metamorfosis ulat hongkong (larva) menjadi pupa ditandai dengan terhentinya sekresi hormon juvenile oleh korpora alata pada stadium larva instar akhir (Riddiford dan Truman 1978). Saefulhadjar (2005) menyatakan bahwa jumlah molting yang tinggi mengindikasikan cepatnya kesiapan ulat untuk segera memasuki tahap pupa, kemudian dewasa (imago) dan bereproduksi. Hasil penelitian pengaruh media pemeliharaan terhadap pertumbuhan ulat hongkong pada persentase keberhasilan pupasi menunjukkan respon berpengaruh nyata $(\mathrm{P}<0,05)$.

Tabel 5. Persentase pupasi pada ulat hongkong umur 28-60 hari

\begin{tabular}{lccr}
\hline Perlakuan & \multicolumn{3}{c}{ Umur (hari ke-) } \\
\cline { 2 - 4 } & $28-38$ & $39-49$ & $50-60$ \\
\cline { 2 - 4 } & 0 & 0 & $28,568 \mathrm{~b}$ \\
\hline Ampas tahu (A) & 0 & 0 & $19,031 \mathrm{~b}$ \\
Dedak padi (D) & 0 & 0 & $5,173 \mathrm{~b}$ \\
Sekam padi (S) & 0 & 0 & $69,667 \mathrm{a}$ \\
Ampas tahu:Dedak padi (AD) & 0 & 0 & $32,641 \mathrm{~b}$ \\
Ampas tahu:Sekam padi (AS) & 0 & 0 & $14,353 \mathrm{~b}$ \\
Dedak padi:Sekam padi (DS) & 0 &
\end{tabular}

Angka yang disertai huruf berbeda menunjukkan hasil yang berbeda nyata $(\mathrm{P}<0,05)$

Persentase memupa pada media pemeliharaan AD sangat tinggi yaitu 69,667\%. Hal ini karena kandungan nutrisi pada media $\mathrm{AD}$ lebih baik dibandingkan dengan media A sebagai kontrol sehingga mempengaruhi siklus hidup ulat yaitu mempercepat proses pupasi pada ulat hongkong. Berdasarkan hasil pengamatan mengenai masa pupasi jika dikaitkan dengan pertambahan bobot badan (PBB), maka dapat dikatakan bahwa level protein $17 \%$ pada media kombinasi ampas tahu kering dan dedak padi, selain memberikan angka PBB yang tinggi dan mengindikasikan kecukupan protein yang dibutuhkan untuk tumbuh optimal, juga mempercepat kematangan ulat 
Tabel 6. Persentase mortalitas ulat hongkong pada umur 28-60 hari

\begin{tabular}{|c|c|c|c|c|}
\hline \multirow[t]{3}{*}{ Perlakuan } & \multicolumn{3}{|c|}{ Umur (hari ke-) } & \multirow[t]{3}{*}{ Rataan } \\
\hline & $28-38$ & $39-49$ & $50-60$ & \\
\hline & \multicolumn{3}{|c|}{$(\%)$} & \\
\hline Ampas tahu (A) & 0 & 11 & $2 d$ & 4.438 \\
\hline Dedak padi (D) & 0 & 5 & $11 b c$ & 5.202 \\
\hline Sekam padi (S) & 0 & 24 & $20 \mathrm{~b}$ & 14.487 \\
\hline Ampas tahu:Dedak padi (AD) & 0 & 0 & $2 d$ & 0,556 \\
\hline Ampas tahu:Sekam padi (AS) & 0 & 6 & $5 c$ & 3.747 \\
\hline Dedak padi:Sekam padi (DS) & 0 & 9 & $21 \mathrm{a}$ & 9.889 \\
\hline
\end{tabular}

Angka yang disertai huruf berbeda menunjukkan hasil yang berbeda nyata $(\mathrm{P}<0,05)$

untuk menjadi pupa. Keadaan ini menunjukkan masa larva menjadi singkat dengan tingkat pertumbuhan yang baik dan mempercepat proses reproduksi atau siklus hidup ulat.

Lambatnya ulat matang yang ditunjukkan dengan sedikitnya jumlah pupa pada kurun waktu yang sama, diperkirakan karena tingginya protein mempengaruhi aktivitas koropora alat ulat untuk memproduksi terus hormon juvenile dalam jumlah banyak (Saefulhadjar 2005). Borror et al. (1982) menjelaskan bahwa dengan semakin rendah suhu lingkungan, maka pertumbuhan ulat hongkong akan lambat, bahkan dapat mencapai 6 bulan.

\section{Mortalitas}

Mortalitas merupakan salah satu parameter yang dapat digunakan untuk mengukur keberhasilan dari pemeliharaan ternak. Hutauruk (2005) menjelaskan bahwa faktor yang dapat menyebabkan terjadinya mortalitas adalah stress yang tinggi akibat suhu dan kelembaban udara yang tidak sesuai, jumlah populasi atau kepadatan dan tempat pemeliharaan serta manajemen pemeliharaan yang kurang baik. Ulat hongkong memiliki daya hidup yang cukup tinggi, terbukti dengan rataan mortalitas yang dihasilkan dalam beberapa penelitian. Hasil penelitian Paryadi (2003) menyatakan bahwa mortalitas ulat hongkong berkisar antara 0,7\%-1,8\%. (rataan 1,25\%) Persentase mortalitas ulat hongkong pada umur 28-60 hari disajikan pada Tabel 6 .

Hasil penelitian pengaruh media pemeliharaan terhadap pertumbuhan ulat hongkong pada persentase mortalitas menunjukkan respon berpengaruh nyata $(\mathrm{P}<0,05)$. Umur 28-38 hari merupakan fase awal pemeliharaan ulat hongkong sehingga persentase mortalitas yang dihasilkan sangat minim yaitu sebesar $0 \%$ untuk masing-masing media pemeliharaan yang digunakan. Ulat hongkong pada umur 39-49 hari mulai memasuki fase molting atau pergantian kulit, media pemeliharaan menggunakan sekam padi 100\% (S) menghasilkan persentase mortalitas yang cukup tinggi yaitu $24 \%$ jika dibandingkan dengan media kontrol (A) yaitu sebesar 11\%. Hal ini disebabkan kandungan nutrisi pada sekam padi sangat rendah sehingga ulat mengalami kegagalan pada proses molting. Bursell (1970) menjelaskan bahwa kekurangan dan atau ketidakseimbangan nutrisi akan mengganggu pertumbuhan dan perkembangan serangga. Ulat hongkong mulai memasuki fase pupasi pada umur 50-60 hari. Persentase mortalitas tertinggi pada umur 50-60 hari dihasilkan pada media pemeliharaan dengan menggunakan kombinasi dedak padi dan sekam padi (DS) yaitu sebesar 21\% jika dibandingkan dengan media kontrol (A) yang hanya mencapai 2\%. Hal ini disebabkan karena media DS mengalami kegagalan pada proses pupasi.

Persentase mortalitas pada media pemeliharaan DS, $\mathrm{D}$, dan $\mathrm{AD}$ mengalami peningkatan pada setiap minggunya, hal tersebut dikarenakan ulat hongkong mengalami kegagalan dalam proses molting dan perubahan larva menjadi pupa. Dedak padi mudah mengalami ketengikan. Ketengikan pada dedak padi dapat disebabkan oleh lemak dan minyak yang mengalami proses hidrolitik dan oksidatif (Wahju 1997). Rataan persentase mortalitas tertinggi adalah menggunakan media pakan sekam padi $100 \%$ (S) yaitu sebesar $14,487 \%$ hal tersebut dikarenakan kandungan nutrisi pada sekam padi sangat rendah sehingga mempengaruhi lama fase pertumbuhan ulat dan menyebabkan mortalitas meningkat. Rataan persentase mortalitas terendah adalah menggunakan media kombinasi ampas tahu kering dan dedak padi (AD) yaitu $0,556 \%$. Media pakan menggunakan kombinasi ampas tahu kering dan dedak padi lebih baik digunakan karena memiliki kandungan nutrisi yang baik untuk pertumbuhan ulat hongkong. Ulat merupakan tahapan larva dari kumbang T. molitor dan merupakan hama butiran, sebagian besar hama butiran dapat hidup pada butiran yang disimpan dengan kadar air 11,5\%-14,5\% (Robinson 1998).

\section{KESIMPULAN}

Media pemeliharaan yang terdiri atas ampas tahu $50 \%+$ dedak padi $50 \%$ lebih baik digunakan dalam pemeliharaan ulat hongkong karena mampu meningkatkan persentase pupasi, dan menurunkan angka mortalitas. Media yang berbeda menghasilkan bobot badan dan pertambahan panjang badan yang sama. 


\section{DAFTAR PUSTAKA}

Anggordi, R. 1990. Ilmu Makanan Ternak Umum. Gramedia Pustaka, Jakarta.

BPS (Badan Pusat Statistik). 2016. Produksi Padi Tahun 2015 Naik 6.42\%. [Internet]. [diunduh 2017 Februari 9]. Tersedia pada https://www.bps.go.id.

Bursell, E. 1970. An Introuction to Insect Physiology. Academic Pr, London.

Bethney Foster. 2003. The Life Cycle of Tenebrio molitor. [Internet]. [diunduh 2017 Oktober 10]. Tersedia pada http://www.ehow.com.

Borror, D. J., C. A. Tripplehorn, \& N. F. Johnson. 1982. Study of Insect. Ed ke-6. Pengenalan Pelajaran Serangga. Penerjemah; Partosoedjono S. Gadjah Mada Univ Pr, Yogyakarta.

Culin, J. 2008. Insect Growth and Development. [Internet]. [diunduh 2017 Oktober 10]. Tersedia pada http:// entweb.clemson.edu.

Flukerfarm. 2005. Fluker's Mealworm Biology Guide. [Internet]. [diunduh 2017 Oktober 10]. Yersedia pada htt[://www.flukerfarm.com.

Frost, W. S. 1959. Insect Life and Insect Natural History. Dover, New York.

Hammond, K. A. 1998. Dietary and Clinical Assesment. Ed Ke-11. Stump SE, editor. Elservier Saunders, Philadelphia.

Hairani, R. S. 2006. Pertumbuhan dan konversi pakan ulat tepung (Tenebrio molitor L.) pada kombinasi pakan koersial dengan dedak padi, onggok dan pollard. Skripsi. Institut Pertanian Bogor, Bogor.

Hartadi, H. L. C., S. Kearl, L. E. Reksohadiprojo, Harris, \& S. Lebdosukoyo. 1980. Tabel-tabel dari komposisi bahan makanan. Data ilmu makanan ternak untuk Indonesia. Gadjah Mada University Press, Yogyakarta.

Haryadi. 2006. Teknologi Pengolahan Beras. Gadjah Mada Univ Pr, Yogyakarta.

Hepburn. 1985. Fundamentals of Insect Physiology. J Wiley, New York.

Hutauruk, S. M. 2005. Performans ulat tepung (Tenebrio molitor) yang diberi pakan campuran onggok dan konsentrat selama masa pertumbuhan. Skripsi. Fakultas Peternakan. Institut Pertanian Bogor, Bogor.

Hsu, H. W., Luh BS. 1980. Rice Product and Utilization. Bor Shiun Luh, editor. Avi Publishing Company, New York.

Ismunadji, M. 1988. Padi Buku I. Badan Penelitian dan Pengembangan Pertanian, Bogor.

Jamroji, M. 2013. Berita Ulat Hongkong. Penebar Swadaya, Jakarta.

Mattjik, A. M., I. M. Sumertajaya. 2013. Perancanagan Percobaan dengan Aplikasi SAS dan Minitab. Institut Pertanian Bogor Pr, Bogor.

Palungkan. 1999. Sukses Beternak Cacing Tanah. Penebar Swadaya, Jakarta.

Partosoedjono, S. 1985. Mengenal Serangga. Agromedia, Bogor.

Paryadi. 2003. Performans ulat tepung (Tenebrio molitor) pada berbagai rasio pemberian pollard dan pakan komersial. Skripsi. Institut Pertanian Bogor, Bogor.

Purwakusuma, K. 2007. Pengendalian Hama dan Penyakit Ikan. Kanisius, Yogyakarta.

Rasyaf, M. 2002. Beternak Ayam Pedaging. Kanisius, Yogyakarta.

Riddiford, L. M., J. W. Truman. 1978. Biochemistry of Insect Hormones and Insect Growth Regulators. Academic Pr, New York.

Robinson. 1998. Introduction to Insect Biology and Diversity. Ed ke-2. Oxford Univ Pr, Oxford.

Rosadi, A. 2001. Pengaruh komposisi beberapa jenis pakan terhadap siklus hidup dan daya produksi telur Cocyra cepholonica Stanton (Lepidoptera, Pyralidae). Skripsi. Institut Pertanian Bogor, Bogor.

Saefulhadjar, D. 2005. Penentuan kebutuhan protein dan energi untuk pertumbuhan ulat tepung (Tenebrio molitor L.). Thesis. Institut Pertanian Bogor, Bogor.

Sari, F. E., 2014. Hartiningsih. Peningkatan bobot badan panen ulat hongkong akibat aplikasi limbah sayur dan buah pada media pakan berbeda. Buana Sains. 14(1):55-64

Sihombing, D. T. H. 1999. Ilmu Ternak. Gadjah Mada Univ Pr, Yogyakarta.

Singh, S. R. 2003. Insect Pets of Topical Legumes. J Wiley, New York.

Sudigdo, E. M. 1983. Kedelai Dijadikan Lebih Bergizi. Terate, Bandung.

Suharno. 1979. Sekam padi sebagai sumber energi alternatif. [Internet]. [diunduh 2017 Februari 9]. Tersedia pada www.smallcrab.com.

Shukla, S. P. 2011. Investigation in to tribo potential of rice hulk (RH) char reinforced epoxy composite. Thesis. National Institute Technology Roukela, Rourkela.

Triplehorn, C. A., Johnson NF. 2005. Study of Insects. Thomson Books, London.

Turut, R. 1998. Sukses Memelihara Burung Berkicau dari Thailand. Penebar Swadaya, Jakarta.

Wahju, J. 1972. Ilmu Nutrisi Ternak Unggas. Gadjah Mada Univ Pr, Yogyakarta.

Widyatmoko, A. 1996. Keon mas (Pomacea sp) dan ampas tahu dalam ransum broiler dengan beberapa peubah [studi pemanfaatan ulat sutra (Bombyx mori linn)]. Skripsi. Institut Pertanian Bogor, Bogor.

Wiglesworth. 1789. Insect and The Feeding of Zoo Animal. Academic Pr, London.

Wiriano. 1985. Pemanfaatan ampas tahu menjadi berbagai macam makanan. Laporan Penelitian. Balai Besar Penelitian dan Pengembangan Industri Hasil Pertanian, Bogor.

Yuni, S. 2001. Pengaruh pemberian ampas tahu dalam ransum terhadap kualitas karkas broiler. Skripsi. Universitas Bengkulu, Bengkulu.

Yusdira, A., A. Haviar, \& Tim Krotobond. 2016. Budidaya Ulat Hongkong untuk Pakan Burung Kicauan, Semut Rangrang, Ikan Hias dan Umpan Pancing. AgroMedia Pustaka, Jakarta. 